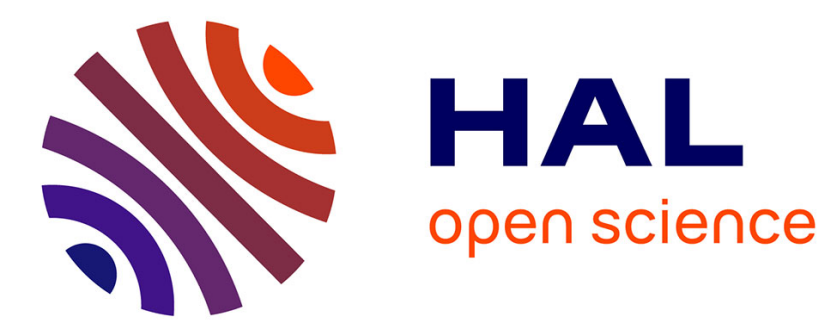

\title{
Reinventing Negation Patterns in Moroccan Arabic
}

Mena B. Lafkioui

\section{To cite this version:}

Mena B. Lafkioui. Reinventing Negation Patterns in Moroccan Arabic. Mena Lafkioui. African Arabic: Approaches to Dialectology, Mouton de Gruyter, pp.51-94 2013, 978-3-11-029232-9. hal01411665

\section{HAL Id: hal-01411665 \\ https://hal.science/hal-01411665}

Submitted on 9 Dec 2016

HAL is a multi-disciplinary open access archive for the deposit and dissemination of scientific research documents, whether they are published or not. The documents may come from teaching and research institutions in France or abroad, or from public or private research centers.
L'archive ouverte pluridisciplinaire HAL, est destinée au dépôt et à la diffusion de documents scientifiques de niveau recherche, publiés ou non, émanant des établissements d'enseignement et de recherche français ou étrangers, des laboratoires publics ou privés. 


\section{Trends in Linguistics \\ Studies and Monographs 258}

Editor

Volker Gast

Founding Editor

Werner Winter

Editorial Board

Walter Bisang

Hans Henrich Hock

Heiko Narrog

Matthias Schlesewsky

Niina Ning Zhang

Editors responsible for this volume

Walter Bisang

Volker Gast

De Gruyter Mouton 


\section{African Arabic: \\ Approaches to Dialectology}

edited by

Mena Lafkioui

De Gruyter Mouton 
ISBN 978-3-11-029232-9

e-ISBN 978-3-11-029234-3

ISSN 1861-4302

Library of Congress Cataloging-in-Publication Data

A CIP catalog record for this book has been applied for at the Library of Congress.

Bibliographic information published by the Deutsche Nationalbibliothek

The Deutsche Nationalbibliothek lists this publication in the Deutsche Nationalbibliografie; detailed bibliographic data are available in the Internet at http://dnb.dnb.de.

(C) 2013 Walter de Gruyter GmbH, Berlin/Boston

Printing: Hubert \& Co. GmbH \& Co. KG, Göttingen

@ Printed on acid-free paper

Printed in Germany

www.degruyter.com 


\section{Contents}

Addresses of contributors ................................................................ vii

\section{Introduction}

Mena Lafkioui.

1

\section{Grammar studies in African Arabic dialectology}

Chapter 1

Stefano Manfredi

Native and non-native varieties of Arabic in an emerging

urban centre of western Sudan. Evidence from Kadugli .....

Chapter 2

Mena Lafkioui

Reinventing negation patterns in Moroccan Arabic

Chapter 3

Shuichiro Nakao

The prosody of Juba Arabic: split prosody, morphophonology, and slang..... .95

Chapter 4

Catherine Taine-Cheikh

Grammaticalized uses of the verb ra(a) in Arabic:

a Maghrebian specificity?

Chapter 5

Xavier Luffin

Some new information about Bongor Arabic. 161 
vi Contents

\section{Lexicological studies in African Arabic dialectology}

Chapter 6

Giorgio Banti

Strata on loanwords from Arabic and other Semitic languages

in Northern Somali

Chapter 7

\section{Lameen Souag}

Sub-Saharan lexical influence in North African Arabic

and Berber

Chapter 8

\section{Peter Behnstedt}

Lexical aspects of Maghrebi Arabic

Chapter 9

Vermondo Brugnatelli

Arab-Berber contacts in the Middle Ages and ancient Arabic

dialects: new evidence from an old Ibādite religious text 271

Index 293 


\section{Reinventing negation patterns in Moroccan Arabic}

\section{Mena Lafkioui}

\section{Introduction}

The present chapter examines how new negation patterns are created in Moroccan Arabic in the Oujda region, North East Morocco, through contact with Berber (Tarifit language, North Morocco, see Figure 1). ${ }^{1}$ The discussed cases concern contact-induced innovation processes in Moroccan Arabic negation, through which the morphological data as well as the syntactic structuring and semantic functioning have been modified by analogy with Berber negation.

The negation system of North African Arabic is fundamentally built on the morphosyntactic opposition between verbal negation and non-verbal negation. Where in the former negation type a verbal component functions as the negation incidence point (generally the verbal predicate or its auxiliary), in the latter type, the negation refers to various nominal elements, such as nouns and prepositions, that generally play the predicative role. Verbal predication is negated by means of the discontinuous marker ma $\check{s}\left(s^{2} / s^{2} a y\right)$ and its optional or conditioned (modal and expressive) variants. The verbal negation structure mainly expresses existential values, whereas the non-verbal negation structure is used for both existential and attributive semantic purposes. The existential negation marker is similar in verbal and non-verbal negation, while attributive negation is mainly marked by the continuous morpheme maši __ or muš __ (or their variants).

With respect to this negation system, the Moroccan Arabic variety of Oujda distinguishes a new discontinuous marker, $m a$ $b u$, whose second element is borrowed from Tarifit, which is the only Berber language where this morpheme occurs (Lafkioui 1996, 1999: II/Chapter 2, 2007: 234-236, 2011a: 62-69). They do not only have this morphological particularity in common, but also its morphosyntactic combinatorial restrictions and syntactic functioning (structural analogy). The hybrid negator $m a$ bu occurs in the following innovated negation patterns: $[m a+$ verbal predicative

1. The dark grey zone on the map corresponds to the Berber speaking area of the Rif that distinguishes this phenomenon. 
syntagm $+b u+$ noun $]$ and $[m a+$ non-verbal predicative syntagm $+b u+$ noun]. Moreover, this Moroccan Arabic variety basically shares the same semantic properties with Tarifit, that is, it is also employed for existential descriptive negation.

The analyses referring to Moroccan Arabic and Berber in this chapter are based on data from my fieldwork in Morocco from 1992 onwards. As for the negation in Tarifit, I also refer to Lafkioui (1996, 1999: II/ Chapter 2, 2007: 234-236 and 2011a: 62-69). The personally gathered data exposed here were transcribed according to the phonological system of the languages at hand, in which only the distinctive value and length of the vowels and consonants are represented. Quoted data, however, are reproduced as such in this contribution. ${ }^{2}$

This introduction is followed by an examination of the negation system in North African Arabic languages (Section 2). In Section 3, the case of Moroccan Arabic is considered in detail by distinguishing between verbal and non-verbal negation and by analyzing their respective morphosyntactic patterns and semantic values. Section 4 addresses the contact-induced innovated negation marker $m a \_b u$ and its combinatorial and distributional implications on the present negation structure and functioning in Moroccan Arabic. The same section is dedicated to the question of borrowing and its development on the basis of the examined data. Finally, this chapter ends with a number of conclusions about contact-induced language variation and its connection with language diffusion and evolution.

2. The following abbreviations are used: AFF 'affix', COMPL 'complement', COP 'copula', DEF 'definite', DET 'determined', DIR 'direct', DIST 'distal', EA 'emphasis accent', F 'feminine', Fo 'pitch', I 'intensity', IMP 'imperative', IMPERF 'imperfective', INDIR 'indirect', INTRG 'interrogative', INVOC 'invocation', M 'masculine', MAX 'maximum', MIN 'minimum', NEG 'negation', NVPS 'nonverbal predicative syntagm', O 'object', $\mathrm{P}$ 'predicate', PART 'particle', PERF 'perfective', PL 'plural' PREP 'preposition(al)', PROP 'proposition(al)', PROS 'prosody', PROX 'proximal', PTCP 'participle', REF 'referential', s 'subject', SG

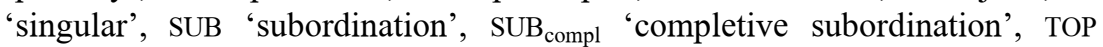
'topic(alization)', UNDET 'undetermined', VPS 'verbal predicative syntagm', $\uparrow$ 'rise in pitch', $\downarrow$ 'fall in pitch'. 


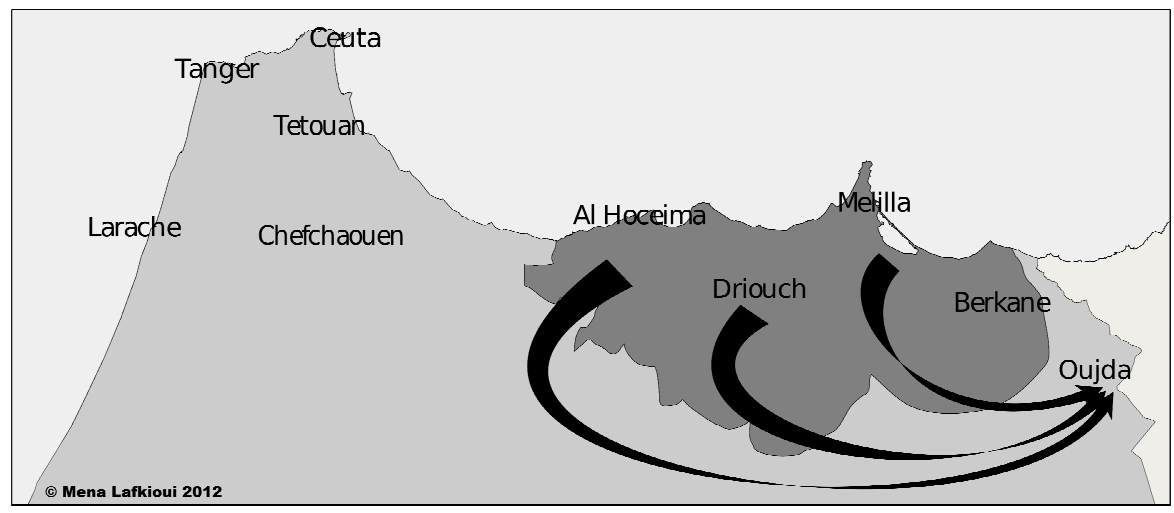

Figure 1. Geographical distribution of negation with marker NEG $b u$

\section{North African Arabic negation}

The North African Arabic negation system is basically composed of the morphosyntactic opposition between verbal negation and non-verbal negation. In the verbal negation structures, the incidence point generally corresponds to the verbal predicative syntagm $(\mathrm{V}+\mathrm{S})$ or a directly related element, whereas diverse nominal elements functioning as the syntactic nucleus are referred to in the non-verbal negation structures. Negation does not engage any morphological modification of the verbal stem of the concerned head. With the exception of Hassaniyya (South Morocco and Mauritania), which uses the morpheme $m a$ _, verbal negation is expressed in North African Arabic through the discontinuous marker $m a$ $\check{s}($ si $/$ šay $)$ and its optional or conditioned variants. ${ }^{3}$ The same marker is used for nonverbal negation in prepositional predicative configurations and when occurring in a conjunctive expressive context, it mostly signifies adverseness; otherwise, non-verbal negation is rendered by means of the continuous marker maši _ or $m u \check{s}$ __ (or their variants), whether evoking existential semantic values (equative, situative, possessive) or attributive ones.

As regards the discontinuous marker $m a$ $\check{s}$ (si/say), both elements are required to negate the verbal predication when no modal, discursive or

3. A similar development is attested in the Arabic variety of the Egyptian Dakhla-Oasis (Woidich 1995-97). 
expressive charge is involved (except Hassaniyya, example 3), as is shown in the next examples:
(1) ma $\quad y-\bar{a} k u l \quad \check{s} \quad$ tawwa.
NEG IMPERF-3MSG-eat NEG now
'He does not eat now.' (Tunisian Arabic; Lafkioui)
$\begin{array}{ll}m \bar{a} & s m \ddot{a} \varepsilon-t-n \bar{l}-\check{s} \\ {[\mathrm{NEG}} & \text { PERF-2MSG-hear+1 } \mathrm{SG}+\mathrm{NEG}]\end{array}$
'Tu ne m'as pas entendu.' (Algerian Arabic; Elhalimi 1996)
['You did not hear me.']
(3) $m \bar{a} \quad$ rgad- $t$
[NEG PERF-1SG-sleep]
'Je n'ai pas dormi.' (Hassaniyya; Taine-Cheikh 1995-96)
['I did not sleep.']

The first element $m a$ is the head negator; ${ }^{4}$ it has a generalized and highly frequent usage in the Arabic spoken varieties, especially in comparison to Classical Arabic, where it is more confined to certain syntactic and semantic contexts. It cannot be omitted under any circumstances but can be substituted by its conditioned variant $l a{ }^{5}$ Besides its basic function of an isolated sentential negation particle, ${ }^{6}$ the latter is also employed for (1) itera-

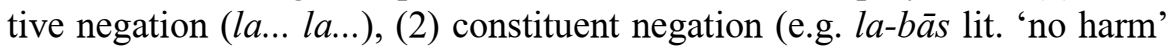
$>$ 'it is okay'), (3) predicative negation of coordinated structures with $u$-la ('or not') or wo-lla ('or not'), (4) expletive negation with subordination, (5) negation of adverbial subordinate clauses denoting purpose and result, and (6) as a composite negative nominal marker (e.g. b-la lit. 'with no' $>$ 'without'). Most of all, though, it appears in semantically and pragmatically marked constructions (e.g. oath, interdiction, order, prohibition, admonition and categorical expressions), such as the next examples:

4. This morpheme is not only employed for negation but also as an interrogative, a relative, an exclamative, and even an indefinite pronoun, which may point to a common origin (Pennacchietti 1967; Wehr 1953).

5. This does not hold for some marginal cases like that of Maltese, where $\check{S}$ is used in constructions engaging modality (Vanhove 1994).

6. Hassaniyya is an exception to this generalized practice because it draws on the particle bdê (*abadan 'never') in order to respond with 'no' (Taine-Cheikh 1995-96). 
(4) allah-la-trabbho-k (Tunisian Arabic; Chaâbane 1996)

[INVOC-NEG-IMPERF-3FSG-succeed+2SG]

'J'implore Dieu pour que tu ne réussisses pas.'

['By God, I wish you will not succeed!']

(5)
la $\operatorname{tg} \bar{\imath} s$
[NEG IMPERF-2MSG-go 3PL]
'Ne vas pas chez eux!'
['Do not go to them!']
hum! (Hassaniyya, Morocco; Iaaich 1996)

So, assertions - actions and states connoted by the realis mood - are negated by different morphemes that are mainly based on the element $m a$ (examples 1 to 3). Other moods, on the other hand, such as the irealis are rather expressed through morphemes containing the element la, often in combination with $\emptyset$ as the second constituent (examples 4 and 5) but also as la __ $\check{s}$ (and free variants). ${ }^{7}$ In the latter case, certain aspects of the expressed modal process or state are highlighted or elaborated (see also Harrell 1962: 153; Elhalimi 1996). However, modality can also be conveyed through the negation morpheme based on $m a$ (or an allomorph), as in example (6). ${ }^{8}$ Apart from modality purposes, the second element of the discontinuous marker may be absent for reasons of discursiveness and heightened expressiveness (example 7), and may be replaced by other elements (i.e. adverbs, indefinite pronouns, relative markers, interrogative markers) that are considered to be semantically or pragmatically more adequate or more expressive (examples 8 and 9). In fact, the second element $\check{s}$, derived from šay? 'thing' of Classical Arabic, was originally an element of intensification (emphasis) - and still is to a different degree in various Arabic varieties - that has lost some of its marking strength with time and therefore had to appeal to other forms to complete this function. Its grammaticalization has reached different stages according to region, and its precise functional roles differ from one variety to another. Compared to the first element, it has a certain distributional flexibility; its position in the syntagm depends on the variable scope of the negation. This innovation phenomenon is absent from Classical Arabic but abundantly observed in the spoken varieties,

7. I have some reservations about Taine-Cheikh's (2000) statement concerning the marginal frequency of $l a \_\emptyset$ in North Africa, especially when it comes to its western part.

8. Interestingly, Maltese Arabic displays the continuous variant $\check{s}$ in modal contexts. 
mainly of North Africa (Marçais 1977; Taine-Cheikh 1995-96), where the data show a remarkable parallelism with the observed phenomena in the current Berber languages, which might have triggered this extended transformation process in North African Arabic (Brugnatelli 1987).

Examples:

(6) w-allāhi hu mo rāgud(Libyan Arabic; Owens 1984: 162)

[INVOC 3MSG NEG PTCP-MSG-sleep]

'I swear he is not asleep!'

(7) l-xdem ma ta-i-ttšra-u (Moroccan Arabic; Youssi 1992: 109)

[TOP NEG PART-IMPERF-3MPL-buy]

'Les esclaves ça ne s'achète pas.'

['Slaves, they are not for buying.']

(8) ma sməe-na hadd (Algerian Arabic; Lafkioui)

[NEG PERF-1PL-hear anybody]

'We did not hear anybody.'

(9) ma fhom-ti hta zafta. (Moroccan Ar.; Lafkioui)

[NEG PERF-2SG-understand even a piece of tar]

'You did not understand a thing.'

The second element $\check{s}$ is principally used for basic negation and thus serves grammatical purposes, whereas its variants $\check{s i}$, šay and $\check{s a y n}$ also play the role of negation intensifier, indicating modality and expressiveness on the enunciative (utterance) level as well as the discursive level (example 10). The element šayn may also behave like an indefinite morpheme signifying a focused 'nothing' (Vanhove 1994).

For example:

(10) la! āna ma nāeəs šāy! (Moroccan Arabic; Caubet 1996) [NEG 1SG NEG PTCP-MSG NEG]

'Mais non! Je ne dors pas du tout!'

[No! I am not sleeping at all!] 
The discontinuous marker $m a$ $\check{s}\left(\check{s i} / \mathrm{s}^{2} \mathrm{y}\right)$ is also attested in non-verbal predication structures, mainly when these refer to existential values:

(11) $m a-f i-h a-\check{s}$ [NEG-in+3FSG+NEG effort]

tasb (Algerian Arabic; Boucherit 2002: 64)

'Il n'y a pas de peine.'

['It is no big deal.']

$\begin{array}{llll}m a & \text { cand }-u & \check{s} & \text { kalma. (Tunisian Arabic; Lafkioui) } \\ \text { [NEG } & \text { at+3MSG } & \text { NEG } & \text { word] }\end{array}$

'He does not keep his word.'

Two major exceptions to this rule are observed. The first is Moroccan, where this morpheme is applied to attributive constructions based on an adjectival predicate, as in the following examples:

(13) ma zwīna $\check{s} \quad$ (,) had r-ṛš̌ma.(Moroccan Arabic; Lafkioui) [NEG pretty NEG PROS PROX DEF-ornament]

'It is not pretty, this ornament.'

(14) la! xu-ya ma qbih-š (Moroccan Arabic; Adila 1996)

[NEG brother+1SG NEG mean+NEG]

'Non! mon frère n'est pas méchant.'

['No! My brother is not mean.']

Discontinuous negation is used here for the purpose of expressiveness, especially when it indicates an adversative meaning and hence a contrastive positioning in the conversational exchange; otherwise, the continuous marker masi would be employed (see below in this section). ${ }^{9}$

The second exception is detected in Libyan Arabic, which allows for the negation of attributive predication by means of the discontinuous marker. It does so, though, on the condition that the predicate is composed of one single term (even a substantive term):

9. In fact, diverse nominals and nominal groups may be negated by the discontinuous marker when they form a kind of 'negative echo' to the preceding utterance (Marçais 1977: 278). 


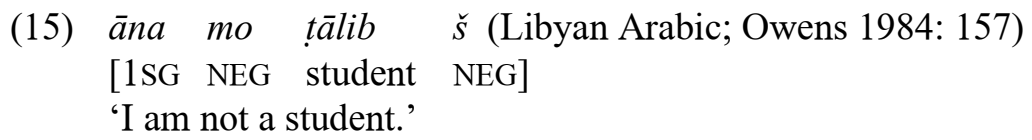

Furthermore, the morpheme $m a \_\check{s}($ sil/say) can be combined with personal pronouns, as affixes or as independent forms, in order to negate all sorts of nominals. While in Tunisian and Maltese mixed structures with affixed and independent pronouns are attested (example 16), in Algerian Arabic, only the amalgam with affixes occurs (example 17), and in Moroccan Arabic, solely the independent pronoun variant is observed (example $18)$.

Examples:

(16) m-īniz $\quad \check{s}$ (Maltese Arabic; Vanhove 1994)

[NEG-1SG NEG]

'I am not...'

(17) $m \bar{a}-h \bar{l}-\check{s}$

$m r e \bar{d}$ da (Algerian Arabic; Elhalimi 1996)

[NEG-3FSG+NEG ill]

'Elle n'est pas malade.'

['She is not ill.']

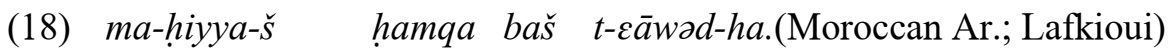

[NEG-3FSG-NEG stupid SUB IMPERF-3FSG-repeat+3FSG]

'She is not so stupid to repeat it.'

It should be noted that in Libyan Arabic a distinction is made between the male and female for the plural forms: man-kam $\check{s}$ (2MPL) $\sim$ man-kan $\check{s}$ (2FPL) and man-hum $\check{s}$ (3MPL) man-hun $\check{s}$ (3FPL).

As to the continuous marker maši (Moroccan, Algerian) or muš $\left(<*[m a+h u+s]\right.$; Tunisian, Libyan ${ }^{10}$, Maltese $)$ and their local variants, they apply to non-verbal negation and refer to semantic values engaging the identification of the speech objects as well as their differentiation (localization and attribution).

10. In Libyan Arabic, this marker varies by (grammatical) gender (Owens 1984: 159): $m \bar{o} \check{s}$ (male) $\sim$ meyš (female). 
Examples:

(19) l-qbāḥa māši mlīha (Algerian Arabic; Elhalimi 1996)

[DEF-malice NEG good]

'La méchanceté n'est pas une bonne chose.']

['Malice is not a good thing.']

(20) āna mōš kibīr (Libyan Arabic; Owens 1984: 159)

[1SG NEG old]

'I am not old.'

These markers precede the term to which the negation relates, which usually corresponds to the predicate but may also be any other constituent of the utterance considered as its enunciative core. Moreover, they require a certain degree of determination of the negated terms. If this is not the case, diverse devices are appealed to that turn the non-verbal structure into a verbal structure, thus necessitating the discontinuous marker; e.g. the situative particle kayn ('there is') and verbal copulas such as kān ('there was') and kaykūn ('there is') in Moroccan Arabic. Furthermore, maši and its variants also mark propositional negation and hence the corresponding focalization procedure.

\section{Moroccan Arabic negation}

\subsection{Verbal negation}

Verbal predication in Moroccan Arabic (except Hassaniyya) is negated by means of the discontinuous marker $m a$ $\check{s}$ (examples 21 to 24$)$ and its optional (examples 25 to 35 ) or conditioned (examples 36 to 48 ) variants.

Examples:

(21) $m a \quad k l a \quad \check{s}$.
NEG $\quad$ PERF-3MSG-eat NEG
'He has not eaten.' 
(22)
ma ka y-ākul
NEG PART-IMPERF-3MSG-eat NEG
'He does not eat.'

(23)

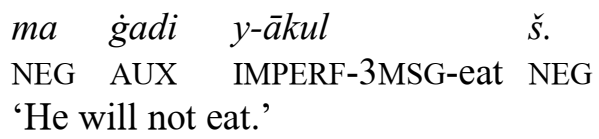

(24) $m a \quad b q a \quad \check{s} \quad$ (ka) $y$-ākul.

NEG AUX NEG (PART)-IMPERF-3MSG-eat

'He does not eat anymore (like he used to).'

All these four utterances exemplify cases of what I call basic negation, in which the negator encloses the predicative syntagm (examples 21, 22, and 23 ) or its verbal auxiliary (example 24). Both segments of the negator are indispensable to the grammaticality of the structure and to the corresponding actualization of the negated message, although some minor cases without the second element, but largely backed up by the referential context, are observed in structures similar to (23) and (24). Furthermore, structures with the auxiliary gadi, which locates the verbal process in the future, like in example (23), make it possible to displace the second element just after the auxiliary, so as to centre the negation on that particular constituent and hence emphasize the temporal dimension of the action described by the head verb. As a result, the negator $\breve{s}$ underscores that the asserted process will not take place in the future (example 28). The dislocation of the second element can also have even heavier semantic implications, for example it might transform a request into an injunction and even lead to shifts in denotative content.

\subsubsection{Optional variants of the discontinuous negation marker}

In this section, I will present the optional variants of the second element of the basic discontinuous marker $m a \_\_r$; the first element remains identical. ${ }^{11}$ In contrast with the basic form, they represent what I label as marked

11. The syntagmatic position of the second element of the negator with ma may also be occupied by different nominal morphemes, such as the adverb $\dot{g} \bar{\imath} r$ ('without'), resulting in the restrictive negator $m a$ $\dot{g} \bar{i} r$ meaning 'not... but...'. 
negation and convey semantic and pragmatic dimensions which are absent from basic negation.

Examples:

$$
\text { ma kla } \quad \check{s i} \text {. }
$$

NEG PERF-3MSG-eat NEG

'He has not eaten at all.'/'I am sure that he has not eaten (at all).'

$$
\begin{array}{lll}
m a & k a y-\bar{a} k u l & \check{s} i . \\
\text { NEG } & \text { PART-IMPERF-3MSG-eat } & \text { NEG }
\end{array}
$$

'He does not eat at all.'/'I am sure that he does not eat (at all).'

$$
\begin{array}{llll}
m a & k a y-\bar{a} k u l & \multicolumn{5}{c}{i} & l-h \bar{u} t . \\
\text { NEG } & \text { PART-IMPERF-3MSG-eat NEG } & \text { DEF-fish } \\
\text { 'He does not eat fish at all.' } &
\end{array}
$$

(28) ma ġadi ši $y$-ākul.

NEG AUX NEG IMPERF-3MSG-eat

'He will not eat at all.'

(29) $m a \quad$ bqa $\check{s} i \quad$ (ka) $y$-äkul.

NEG AUX NEG (PART)-IMPERF-3MSG-eat

'He does not eat at all anymore (like he used to).'

The second element $\breve{s i}$ (or its variant $\check{s a y}$ ) generally tends to avoid subsequent elements. Even if examples (27), (28) and (29) are grammatically correct, they are generally not considered as idiomatic, unless their second negation element is marked by an emphasis accent $(\mathrm{EA}=\{\mathrm{Fo} \uparrow, \mathrm{I} \uparrow\})$ initiating on the final syllable of the preceding constituent (i.e. emphatic negation). It is the presence of this intensifier - highly accentuated in these examples and therefore more expressive - that makes it possible to convey the idea of categoricalness and absoluteness in addition to the negation of the verbal process, including its particular dimensions (temporal, aspectual, modal). An example of this is the temporal determination in example (28), rendered by the auxiliary gadi, and the aspectual determination in example (29) that is sustained by the auxiliary bqa. In case of aspectual determination, the negation process does not completely 
invalidate the positive charge of the asserted content; for instance, example (29) does suggest that the referential object ate before.

The reluctance of accepting subsequent elements, especially nominal complements, after the negation intensifier may have to do with its function as a "forclusif", to use Tesnières' (1959: 225) terminology. This is the function that connects the enunciative content to some negative idea - to various possible degrees - after being detached from the positive corresponding idea by the "discordantiel". As the presence of more than one forclusif is useless and therefore not preferred, because a negative notion is already attached to the asserted content by the first forclusif - Arabic ši (or variants) as a forclusif tries to avoid subsequent elements. But this restriction is not applied when the elements are detached from the enunciative core, and hence also from the negation scope, by emphasizing the forclusif prosodically (emphasis accent). Therefore, it is more than likely that Arabic, and more precisely the North African varieties, has a bipartite negation that arose from the developed innovated discontinuous negation markers. $^{12}$

\begin{tabular}{c} 
Bipartite negation $=$ \\
discordantiel $m \boldsymbol{m}$ or variants (first part; disconnecting device) \\
$\quad+\quad$ \\
forclusif $\check{\boldsymbol{s}}$ or variants (second part; connecting device). \\
\hline
\end{tabular}

The same semantic values and combinatorial and distributional restrictions are attributed to verbal negation with $\check{s a y}$ as an intensifier (examples 30 and 31).

Examples:

(30) ma kla šay.

NEG PERF-3MSG-eat NEG

'He has not eaten at all.'/'I am sure that he has not eaten (at all).'

12. The hypothesis of a bipartite negation for the North African varieties is suggested in Taine-Cheikh (1995-1996), even if the case under investigation, Hassaniyya of Mauritania, ignores this phenomenon. 


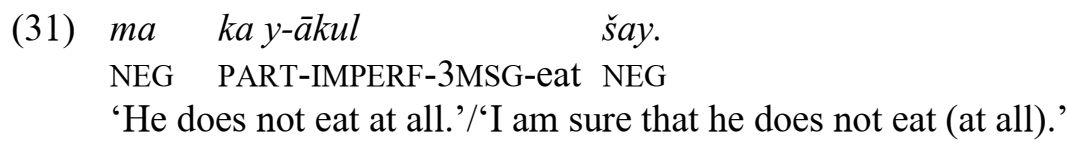

The negator $m a \_\emptyset$ is optional when it is associated with Perfectives sustained by verbal auxiliaries that express the notion of 'still', 'maintain', 'remain' so as to signify the phrase 'not... yet' (affective polarity):

(32) bāqi ma sālī-ti?

AUX NEG PERF-2SG-finish

'Haven't you finished yet?'

(33) bāqi ma sālì-ti

AUX NEG PERF-2SG-finish NEG

'Haven't you finished yet?'

(34) $r \bar{a}-n i \quad m a z a \bar{l} \quad m a \quad b d \bar{l}-t$.

PART+1SG AUX NEG PERF-1SG-start

'I have not started yet.'

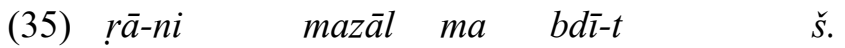

PART+1SG AUX NEG PERF-1SG-start NEG

'I have not started yet.'

Aside from this restrictive rule, the alternative optional variant (examples 32 and 34) does not engage any distinctive feature compared to the basic negation structure (examples 33 and 35 respectively), at least if no prosodic emphasis is put on the second element $\check{s}$, which would delimit the negation scope precisely.

\subsubsection{Conditioned variants of the discontinuous negation marker}

The conditions under which the variants classified in this category appear are diverse, but mainly have modality and expressiveness in common, as will be demonstrated in this section. Moreover, in most cases, the presence of $\emptyset$ as the second element of the negation morpheme is a distinctive feature of this type of variants. 
The discontinuous marker $m a$ $\emptyset$ is necessarily used in oaths and categorical expressions (examples 36, 37, 38, 39, and 40). These may be introduced by religious locutions such as wollah ('By God!', also denoting 'I swear!') in example (36) or by the adverbial locution eammar- $(<*$ *amr 'life' $+m a \_\emptyset>$ 'never'), which is always followed by a personal affix that fully agrees with the subject of the predication (examples 37, 38, 39, and 40). The negation marker $m a$ succeeds the latter locution (example 37), precedes it (example 38 ) or even occupies both syntagmatic positions (example 39); in the last option, more semantic definiteness and energy is added to the negated message. In cases like (37) and (39) - and even (38) with a proper intonation - the syntagm [Eammor- + personal affix] is inevitably subject to topicalization, which is mainly marked by specific intonation features, such as an intonation rupture and pitch dominance. ${ }^{13}$

Examples:

$\begin{array}{llll}\text { wollah } & m a & h d \partial r-t & f i-h ! \\ \text { INVOC } & \text { NEG } & \text { PERF-1SG-talk } & \text { in+3MSG }\end{array}$

'I swear I did not talk about him!'

\begin{tabular}{|c|c|c|c|}
\hline $\begin{array}{l}\text { عammər-ha } \\
\text { never+3FSG }\end{array}$ & $\begin{array}{l}m a \\
\text { NEG }\end{array}$ & $\begin{array}{l}m s ̌ \bar{a}-t \\
\text { PERF-3FSG-go }\end{array}$ & $\begin{array}{l}\text { l-h̆mmām! } \\
\text { DFF-hammam }\end{array}$ \\
\hline
\end{tabular}

(38)
ma Eammor-ha mš̄- $t$
l-h̆mmām!
NEG never+3FSG PERF-3FSG-go DEF-hammam
'She never went to the hammam!'

$\begin{array}{lllll}\text { (39) } m a & \text { cammər-ha } & m a & m \check{s} \bar{a}-t & \text { l-ḩmmām! } \\ \text { NEG } & \text { never+3FSG } & \text { NEG } & \text { PERF-3FSG-go } & \text { DEF-hammam } \\ \text { 'She never ever went to the hammam!' } & \end{array}$

Even though Moroccan Arabic displays a slight combinatory preference for the Perfective in negative oaths with $m a$ $\emptyset$, constructions with the Imperfective (without TAM marker) are also attested; example (36) would be 'wallah ma nə-hdor fi-h!' ('I swear I will not talk about him!'). It should also be mentioned that Moroccan Arabic makes it possible to denote the

13. These findings are based on my project in progress on "Intonation and Topicalization" (Lafkioui 2002, 2010, 2011c). 
basic meaning of examples (37) to (39) without inserting any negation particle, albeit in a more subsidiary way. This is illustrated in the following example:

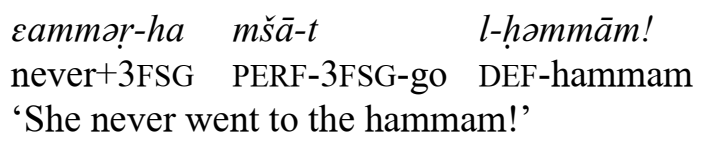

A diachronic change scenario that could account for this phenomenon is the following: the constituent Eammor-, originally a noun grammaticalized into an adverb of frequency, is grammaticalized into a negation adverb. This process is favoured by its topicalized form, which is prosodically highly marked and so produces its detachment from the rest of the utterance. ${ }^{14}$ Put differently, this means that the topicalization of a specific adverbial use could have sustained the development of a new pre-head negation marker (Eammor-) in contexts where the initial negators $\left(m a+m a \_\emptyset\right.$ and $m a$ $\emptyset)$ have vanished for reasons of semantic weakness. Consequently, as عammor- combines with $m a$ $\emptyset$, it might have been reanalyzed as a dislocated forclusive before its grammaticalization as a negation adverb.

Another topicalized adverbial determinant that frequently occurs in negated structures with $m a$ $\emptyset$ is $g \bar{a} \varepsilon$ ('all', 'at all'), used to signify the meaning 'not at all', like for instance in example (41):

$$
\begin{aligned}
& \text { gāe ma bqa tom. } \\
& \text { all NEG PERF-3MSG-stay there } \\
& \text { 'He did not stay there at all.' }
\end{aligned}
$$

The same marker recurs in negation constructions containing the verb eraf ('to know') as a predicate if it is an Imperfective without preverbal TAM markers: ${ }^{15}$

14. I am grateful to Vermondo Brugnatelli, who drew my attention to the Italian adverb affatto ('absolutely', 'utterly') that has recently undergone a somewhat similar development in spoken Italian, viz. the negation adverb meaning 'no' or 'not at all' generally used as a negative response in configurations without a negation marker.

15. Mostly for the $1 \mathrm{~S}$; otherwise, the presence of the second part of the discontinuous negator is preferred. 


$\begin{array}{lll}\text { ma } & \text { n-arraf } & \text { māl-hum. } \\ \text { NEG } & \text { IMPERF-1SG-know what about+ 3PL } \\ \text { 'I do not know what is wrong with them.' }\end{array}$

Another combinatorial context in which this negator is regularly detected is $\left[m a+\mathrm{VS}+\emptyset+\mathrm{O}\left(=\mathrm{SUB}_{\text {compl }}\right)\right]$.

For example:

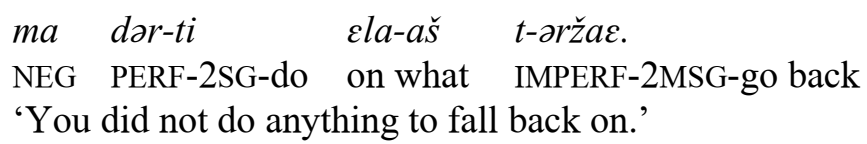

Besides its use in verbal constructions with a completive subordinate clause as the direct complement (example 43), this marker is also brought into play in verbal negation structures with an indefinite direct complement, as in the next example:

Interestingly, this predicative structure is compatible with the second element $\check{s}$ (or allomorphs) if there is a contrastive conjunction in which the second part is explicitly uttered or just presupposed. For example, if utterance (44) contained the element $\check{s}$, a conjunctive part such as 'dor-ti wālu' ('you did nothing') would implicitly be present. Furthermore, this morpheme adds some referentiality to the dereferentialized nature of this negation type that is supported by the undetermined direct object; (44) would thus mean 'You haven't got any children?' with a focus on 'any'.

As regards the discontinuous marker la $\emptyset$, it is employed in the context of negative prohibitions, injunctions and oaths; the former may also be expressed through the markers $l a$ $\check{s}$ and $m a$ $\check{s}$, like in example (46). Yet, prohibitions with $\emptyset$ as the second negation element, such as the one presented in example (45), are more energetic. An appropriate exclamative intonation is of course a conditio sine qua non for the syntactic adequacy 
of this utterance, as well as for its semantic and pragmatic function (prohibition). In addition, an asymmetrical relationship is observed in Moroccan Arabic - as well as in Arabic in general - between the negative prohibition structure, based on the Imperfective, and its matching positive configuration, i.e. that of the Imperative, which draws on a different conjugation paradigm (only $2 \mathrm{~S}$ and $2 \mathrm{P}$ ) and employs dissimilar personal affixes.

Examples:

$l a \quad t$-əhrəb!
NEG IMP-2MSG-run away
'Do not run away!'

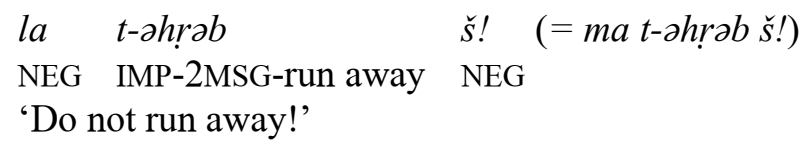

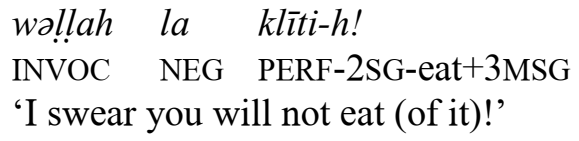

Concerning the negation of oaths and wishes (example 47), like most North African Arabic varieties, ${ }^{16}$ Moroccan Arabic has conserved the flip-flop phenomenon detected in Classical Arabic. This phenomenon consists of using the Perfective - usually indicating the idea of completion - in contexts situated or projected in the future. Accordingly, this type of negation conveys the inexistence of a process or a state positioned in the future. ${ }^{17}$

\subsubsection{Verbal negation patterns}

As shown in the data examined in the previous sections and some of the examples that I replicate here, verbal negation follows a pattern in which the discontinuous negation markers generally encircle the predicative syntagm or one of its components.

16. Yet, this feature is often absent in other Arabic speaking parts of the world.

17. About this phenomenon in North African Arabic, see also (among others) Aguadé and Elyaacoubi (1995: 148) and Taine-Cheikh (2000). 
Examples:

$(21)$

$\begin{array}{lll}m a \quad k l a & \check{s} . \\ \text { NEG PERF-3MSG-eat } & \text { NEG } \\ \text { 'He has not eaten.' } & \end{array}$

$(22)$

$\begin{array}{lll}m a & k a y-\bar{a} k u l & \check{s} . \\ \text { NEG } & \text { PART-IMPERF-3MSG-eat } & \text { NEG } \\ \text { 'He does not eat.' } & \end{array}$
gāe $\quad m a \quad b q$
tom.
all NEG PERF-3MSG-stay there
'He did not stay there at all.'
(45) la t-əhrəb!
NEG IMP-2MSG-run away
'Do not run away!'

The first element always precedes the predicative syntagm, even if the second element is $\emptyset$ (examples 41 and 45).

\section{General verbal negation pattern: \\ $(\mathrm{COMPL}+) \mathrm{NEG}+\mathrm{VPS}+\mathrm{NEG}(+\mathrm{COMPL})$}

However, it should be specified that when the VPS contains a verbal auxiliary, the negation markers may merely enclose the latter instead of the whole predicative syntagm, depending on the negation scope (example 24 repeated below, but also 28 and 29 in Section 3.1.1.). The fact that the auxiliary of these examples is fully conjugated in agreement with the head verb underpins its predicative function. In contrast, when the auxiliary is a grammaticalized form (invariable unit or group of units), usually playing the role of an adverbial determinant that occupies the initial position of the sentence, the negation proceeds according to the general pattern, as in examples (33) and (35). 
Examples:

$$
\begin{aligned}
& m a \quad b q a \quad \check{s} \quad(k a) y \text {-ākul. } \\
& \text { NEG AUX NEG (PART)-IMPERF-3MSG-eat } \\
& \text { 'He does not eat anymore (like he used to).' }
\end{aligned}
$$

$\begin{array}{llll}b \bar{a} q i \quad m a & s \bar{a} l \bar{l}-t i & \check{s} ? \\ \text { AUX NEG } & \text { PERF-2SG-finish } & \text { NEG } \\ \text { 'Haven't you finished yet?' } & \end{array}$

$\begin{array}{lllll}r \bar{a}-n i & m a z \bar{a} l & m a & b d \bar{l}-t & \check{s} . \\ \text { PART+1SG } & \text { AUX } & \text { NEG } & \text { PERF-1SG-start } & \text { NEG } \\ \text { 'I have not started yet.' } & & \end{array}$

So, the second element of the negation marker sets the limits of the negation scope and hence determines specific aspects of the actualized or projected process or state, which may be highlighted by means of prosodic devices (intonation and accent). With respect to the precise negation scope, the marker $\check{s}$ may follow the indirect affix, as in (48), but may also precede it when the direct object is emphasized:

\begin{tabular}{|c|}
\hline $\begin{array}{c}\text { Alternative verbal negation pattern I: } \\
(\mathrm{COMPL}+) \text { NEG + VPS + DIR COMPL }(=\mathrm{AFF} 1) \\
\text { + INDIR COMPL }(=\mathrm{AFF} 2)+\mathrm{NEG}\end{array}$ \\
\hline $\begin{array}{c}\text { Alternative verbal negation pattern II: } \\
(\mathrm{COMPL}+) \mathrm{NEG}+\mathrm{VPS}+\mathrm{DIR} \text { COMPL }(=\mathrm{AFF} 1) \\
\text { + NEG + INDIR COMPL }(=\mathrm{AFF} 2)\end{array}$ \\
\hline
\end{tabular}

$$
\begin{array}{llll}
m a & g \bar{a} l-u-h a & l-u & \check{s} \\
\text { NEG } & \text { PERF-3PL-tell+3FSG } & \text { to+3MSG } & \text { NEG } \\
\text { 'They did not tell him that.' } & &
\end{array}
$$

\subsection{Non-verbal negation}

Non-verbal predication in Moroccan Arabic is negated by means of both continuous and discontinuous markers. The continuous markers, on the one hand, are principally used in descriptive contexts, that is, to identify or to 
distinguish and to localize the discursive objects described by means of the nominal elements that constitute the utterance. The discontinuous markers, on the other hand, serve more expressive goals, which often relate to modality.

\subsubsection{The continuous negation marker}

Non-verbal negation in Moroccan Arabic is generally expressed through the continuous marker maši , as is revealed in the following examples:

maši $\quad d$-drāri $\quad l-k a d d \bar{a} b a$.
NEG DEF-children DEF-liars
'The children are not the liars.'

(50) maši $\quad b b^{w} a-h$.

NEG father+3MSG

'It is not his father.'

(51)
l-warqa
(,) maši
rqīqa
$b a z z \bar{a} f$.
DEF-pastry dough PROS NEG thin very
'The pastry dough, it is not very thin.'

The nominal predicate of these utterances points to a referential identification (examples 49 and 50) or a qualitative attribution (example 51) of the discourse object. The predication in example (52), on the other hand, indicates its localization in the inter-subjective space:
$\begin{array}{ll}\text { maši } & \text { hna. } \\ \text { NEG } & \text { here }\end{array}$
'It is not here.'

The marker maši thus precedes the syntagmatic constituent to which the negation relates, which can be the subject of the predication (example 49), its predicate (examples 50 and 51), a complement, or even the whole predicative configuration (example 62, see infra).

In case of an identification relationship between the predicative constituents (examples 49 and 50), the negator maši also functions as a predicative auxiliary (i.e. negative copula), a role that is played by an independ- 
ent personal pronoun in the corresponding positive nominal configuration (example 53). The pronoun in question is restricted to the third person; i.e. $h u w(w) a(3 \mathrm{MSG}), h i y(y) a(3 \mathrm{FSG})$ and huma (3PL) in agreement with [S-P] or $[\mathrm{P}]$.

Examples:

$\begin{array}{lll}\text { d-drāri } & \text { huma } & \text { l-kaddāba. } \\ \text { DEF-children } & \text { 3PL } & \text { DEF-liars }\end{array}$

'The children are the liars.'

$* d$-drāri l-kaddāba
DEF-children DEF-liars
'the lying children'

The personal pronoun huma, which separates the subject (the first term) from the predicate (the second term) in the positive structure (example 53) may appear in the negation structure, not as a predicative auxiliary but as a deictic emphasizing certain aspects of the referential process; in the present case, the subject is emphasized: ${ }^{18}$

$\begin{array}{llll}\text { maši } & d \text {-drāri } & \text { huma } & \text { l-kaddāba. } \\ \text { NEG } & \text { DEF-children } & \text { 3PL } & \text { DEF-liars }\end{array}$

'It is not the children who are the liars.'

As regards attributive negation, the predicate can be focalized by inverting the syntagmatic order and hence by positioning the subject after the predicate. These are then both separated by an intonation rupture, as for instance in the cleft structure in (56), based on example (51):
maši rqīqa bəzzāf (,) l-warqa.
NEG thin very PROS DEF-pastry dough

'It is not very thin, the pastry dough.'

The intonation features are highly demarcative in the case of a focalized negative configuration - the intonation break in (56) is much more distinctive than in (51) - as well as in the case of a basic positive configuration

18. This implies a corresponding focalization. 
(example 57), where these are essential to distinguish the subject from the predicate:
l-warqa
(.) rqīqa bəzzāf.
DEF-pastry dough PROS thin very
'The pastry dough, it is very thin.'

Furthermore, in adversative contexts, the negation of an attributive predication may proceed through the discontinuous marker (see also Section 3.2.2.). For instance, if the interlocutor contests the quality attributed to the pastry dough described in example (57), he or she would utter one of the following options:

$\begin{array}{lllll}\text { lwarqa } & \text { (,) } m a & \text { rqīqa } & \check{s} & \text { bazzāff. } \\ \text { DEF-pastry dough } & \text { PROS NEG thin } & \text { NEG } & \text { very } \\ \text { 'The pastry dough, it is not very thin.' } & & \end{array}$

$\begin{array}{llllll}m a & \text { rqīqa } & \check{S} & \text { bazzāf } & \text { (,) } & \text { lwarqa } \\ \text { NEG thin } & \text { NEG } & \text { very } & \text { PROS } & \text { DEF-pastry dough } \\ \text { 'It is not very } & \text { thin, }\end{array}$

'It is not very thin, the pastry dough.'

Regarding the negation of locative predications, Moroccan Arabic makes use of the continuous marker maši if its components are determined (example 52 supra and 60 infra). Otherwise, existential markers such as the invariable marker kayn ('there is') and the variable kān ('there was') and kaykūn ('there is') are employed, as in example (61):
(60) $\quad l-h ̣ l i ̄ b$
maši $f \quad t$-tallāža
DEF-milk NEG in DEF-fridge
'The milk is not in the fridge.'
(61) ma kayn $\check{s}$ hlīb f t-tallāža NEG COP NEG milk in DEF-fridge 'There is no milk in the fridge.'

Besides predicative negation, which has a particular term of the predication as the incidence point (usually the predicate), there are also numerous cases of propositional negation (sentential negation) - with the whole proposition, behaving like a nominalized syntagm, as the incidence point. 
For example:

$$
\begin{array}{lll}
\text { maši } & \text { găl-ha } & l-u . \\
\text { NEG PERF-3MSG+3FSG } & \text { to }+3 \mathrm{MSG} \\
\text { 'It is not that he told him that.' }
\end{array}
$$

It is the asserted proposition $g \bar{a} l-h a l-u$ ('he told him that') that is denied in this utterance and not its verbal head gāl ('he told'), which would generally be negated by means of a discontinuous marker if it were the predicate:

$$
\begin{array}{llll}
m a & g \bar{a} l-h a & \check{s} & l-u . \\
\text { NEG } & \text { PERF-3MSG+3FSG NEG } & \text { to+3MSG } \\
\text { 'He did not tell him that.' } &
\end{array}
$$

\subsubsection{Discontinuous negation markers}

Adjectival predicates are negated by means of the continuous marker maši (example 51 in Section 3.2.1.) as well as by the discontinuous marker $m a \_\check{s}$ (or its more expressive variants $m a \_s ̌ i$ and $m a \_\check{s} a y$ ), as presented previously (examples 13 and 14 in Section 2) and also in the next non-verbal utterance:

(64) ma rqīq $\check{s}$.

NEG thin NEG

'He is not thin.'

It is the quality of 'being thin' that is negated in this example; this feature is asserted as being invalid with respect to the referential object, that is, a male person about whom the interlocutors are talking. This case of predicative negation could therefore be glossed as follows: 'The quality of being thin is not attributed to the person about whom we are speaking'. But when the same adjective is negated by the continuous marker, it signifies 'It is not that he is thin':

(65) maši rqīq.

NEG thin

'It is not that he is thin.' 
Discontinuous negation of the type presented in (64) also entails the idea of disagreement, as it were the first part of a bipartite opposing structure, of which the second part is implied or explicitly uttered, like in the following example:

$m a \quad$ rqīq $\check{s}, \quad \dot{g} l \bar{l} d$.
NEG thin NEG PROS big
'He is not thin; he is (rather) big.'

Predication based on prepositional constructions uses the discontinuous marker $m a \_\_\check{s}$ for negation (examples 67 and 68). This marker surrounds the predicative syntagm, composed by the preposition and its personal affix, which is sufficient for a valid assertion when supported by the referential context (example 68). This example may be used, for instance, as a negative response (initiating with la... 'No.') to the question $h \bar{u}-k$, $\varepsilon a n d-u$ tumubilla? ('Your brother, does he have a car?'). However, this utterance lacks the object complement (or its topicalized variant), which is essential to the grammaticality of this type of non-verbal structure (example 67): NVPS (=PREP + AFF $)+\mathrm{O}_{\text {obligatory }}$.

\begin{tabular}{llll}
$m a \quad$ cand-u & \multicolumn{5}{c}{} & tumubìla \\
$\mathrm{NEG}$ at+3MSG & NEG & car \\
'He hasn't got a car.'
\end{tabular}

(68) $\quad m a \quad \varepsilon a n d-u \quad \check{s}$.

NEG at+3MSG NEG

'He hasn't got (it).'

In addition, the syntagmatic structure of example (68) is ambiguous: on the one hand, it represents the syntactic core of a possessive assertion with an elliptic object complement $([\mathrm{P}+\mathrm{S}]$ order). This is for example the case when it refers to (67). On the other hand, it also stands for a locative assertion in which the prepositional group functions as the predicative syntagm with an elliptic subject ([S+P] order). If there is a complete structure, it could look as follows:

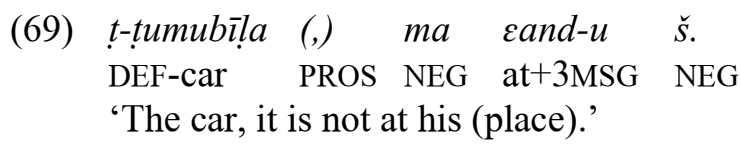


However, in case of a locative structure, continuous negation with masi __ is largely preferred, which is the principal negator of non-verbal structures, especially when the first term is explicit and hence determined. Conversely, with a possessive structure, the discontinuous marker ma _ $\check{s}$, typical of verbal negation, is favoured. This evidence corroborates the verbalization hypothesis of Cohen (1984), which is also supported by the fact that possessive non-verbal predication displays a word order that is distinctive for verbal predication in Arabic $([\mathrm{P}+\mathrm{S}])$, in contrast with the common non-verbal word order $([\mathrm{S}+\mathrm{P}]$; for example, locative predication). Thus, Cohen's (1984: 585) idea that nominal structures may evolve to "quasi-verbal" structures in some Semitic languages and hence exhibit syntactic features characteristic of verbal structures also applies to Moroccan Arabic and Hassaniyya (Taine-Cheikh 1995-96). Interestingly, this phenomenon is also widely attested in Berber (Lafkioui 1999, 2011a: Chapter 1), which offers an interesting field for comparative study that could extend to the Afro-Asiatic level.

Moreover, the morpheme $m a \_r$ (or variants) is compatible with independent personal pronouns in order to negate various nominals and nominal groups, such as in example (18) (see Section 2). The nominal head may also contain the particle $r \bar{a}$, which does not only place the expressed notion (process or state) in the Present Continuous (aspectual-temporal particle), but above all refers to the inter-subjective space between the interlocutors and their respective place and discursive commitment. ${ }^{19}$ Here again, Berber displays a remarkable similarity, as it provides accounts of specific but similar particles that indicate how the interlocutors are involved in their interactions (Lafkioui 1999, 2011a: Chapter 1).

It should also be noted that diverse nominals and nominal combinations are negated by means of this discontinuous morpheme when they constitute a negative response that repeats the core content of the directly preceding question:

$\begin{array}{llll}\text { (70) fin huwa ? } & \text { hāraž } & ? \\ \text { INTRG } & \text { 3MSG PROS } & \text { PTCP-MSG-go out } & \text { PROS } \\ \text { 'Where is he? Out?' } & & \end{array}$

19. For more about this particle, see Taine-Cheikh's chapter in this volume. Another interesting contribution regarding $r \bar{a}$ in Moroccan Arabic is Caubet (1992). 

(71) la , ma hāarəž $\check{s}$.
NEG PROS NEG PTCP-MSG-go out NEG
'No, he is not out.'

Like verbal negation (examples 44 and 43, respectively, of Section 3.1.2.), nominal constructions with an indefinite noun (example 72) or a completive subordinate clause (example 73) as the object complement require the discontinuous marker $m a$ $\emptyset$ for negation. ${ }^{20}$

Examples:

$\begin{array}{lll}\text { ma } & \text { mea-kum } & \text { hadra. } \\ \text { NEG } & \text { with+2PL } & \text { talk }\end{array}$

'There is no sense in speaking with you.'

(73) ma eand-na fin n-əmši-w.

NEG at+1PL where IMPERF-1PL-go

'We haven't got anywhere to go.'

But, as mentioned before for verbal configurations, if the interlocutor wishes to focus on a particular constituent of the predication by adding some referentiality to the expressed content, he inserts the element $\check{s}$ (or a variant) just at the end of the negation scope; in examples (72) and (73), this insertion could only occur after the prepositional syntagms.

\subsubsection{Non-verbal negation patterns}

Non-verbal negation distinguishes between two distributional patterns: the first one concerns continuous negation and assigns a pre-predicative position to the single negator maši, which is the principal marker of non-verbal negation. The second one is discontinuous and corresponds to the general morphemic order detected for verbal negation, that is, the first element $m a$ precedes the syntactic head while the second element $\breve{s}$ follows the final constituent of the negation scope.

20. This is another point that supports the idea that certain nominal structures have been subject to a verbalization dynamic. 
Non-verbal continuous negation pattern:

NEG + NVPS

For example:

(74)

huwa maši $b b^{w} a-h$.
3MSG NEG father+3MSG
'He is not his father.'

The basic word order of predicative negation built on maši is [S + NEG + $\mathrm{P}$ ], when $\mathrm{S}$ is uttered in sentences with an identification (example 74), attributive or locative value. The $S$ term of locative predication should be determined. If not, a copula is employed, which brings discontinuous negation into play. Discontinuous negation is also used in attributive and locative constructions for adversative purposes.

Focalization of $\mathrm{P}$ is established by inverting this basic syntagmatic order and marking the focus by prosodic means (e.g. intonation break) that at the same time separate the subsequent $\mathrm{S}$ from $\mathrm{P}$ (example 75 here below and also example 56 in Section 3.2.1.): $[\mathrm{NEG}+\mathrm{P}+\mathrm{PROS}+\mathrm{S}]$.

For example:
maši $\quad b b^{w} a-h$
(,) huwa
NEG father+3MSG PROS $3 \mathrm{MSG}$
'It is not his father.'

Propositional negation follows the general continuous negation pattern, i.e. [NEG + PROP].

As regards discontinuous negation, the marker $m a$ $\check{s}$ is detected in specific contexts when applied to non-verbal predication. Apart from contexts indexing referential and adversative(-conjunctive) meanings, it mainly appears with adjectival predicates (example 64 of Section 3.2.2.) and prepositional predicative syntagms (examples 67, 68, and 69 of Section 3.2.2.). The basic word order of this negation type is [S + NEG + P + NEG]. Only predication expressing the idea of possession has a different (inverse) order, namely $[\mathrm{NEG}+\mathrm{P}+\mathrm{S}+\mathrm{NEG}]$. Moreover, when $\mathrm{O}$ is represented by an indefinite nominal or by a completive subordination, non-verbal negation is marked by means of $m a$ $\emptyset$, if no referential connection is involved. 
Non-verbal discontinuous negation pattern:

$\mathrm{NEG}+\mathrm{NVPS}+\mathrm{NEG}(+\mathrm{COMPL})$

\section{Innovations in Moroccan Arabic negation}

The mutual influence between Arabic and Berber in North Africa has been attested in diverse linguistic domains (i.e. phonetics, morphology, syntax and lexicon). It varies with respect to different parameters, of which the geographical, historical and social ones are fundamental, in addition to the system-based parameters. Negation is one of the major research fields that is subject to contact-induced change in North Africa. An important aspect of this field is the emergence of discontinuous negation markers in North African Arabic, an innovation that is largely generalized over North Africa's Arabic speaking zones and that could have been created by contact with Berber - where these markers are common and highly developed in many languages. However, the influence might also have occurred in the other direction; that is, Berber might have borrowed post-head negation marking from Arabic, as this feature is also attested outside Berber speaking areas, mainly in some Egyptian and Levantine varieties. ${ }^{21}$ Even so, the case investigated in this chapter, Moroccan Arabic of Oujda, clearly shows specific borrowing phenomena from Berber into Arabic, as will be demonstrated in this section and in the subsequent one. But before going into detail, a presentation of the Berber negation system is needed in order to better understand the contact phenomena explained.

Like North African Arabic, the Berber negation system basically draws on a distinction between verbal negation, mainly marked by discontinuous morphemes, and non-verbal negation, characterized by continuous marking procedures. The principal distinctive feature between these two negation systems is that most Berber languages also mark negation by means of verbal stem alternation, in which the Negative Perfective is more prevalent than the Negative Imperfective. Furthermore, the presence of preverbal negators generally leads to a syntagmatic position change of the postverbal affixes (fronting); they precede the verbal head (but follow the negator),

21. The hypothesis that discontinuous negation in Berber has been borrowed from Arabic (Lucas 2007) is interesting but unconvincing for different reasons, the main reason being that the Berber data on which the analysis is based are too scarce on a comparative level and therefore inconclusive as evidence. 
usually without modifying their respective order, namely [indirect affix + direct affix].

The predominant variant of the first element of the discontinuous negator is presumably of Berber origin and is derived from *war, a grammaticalized verbal form composed of the negation element $* w$ or $* u$ and the verbal root $* r$ (expressing modality): ${ }^{*} w a r=\mathrm{NEG}=[\mathrm{NEG} * w$ or NEG $* u$ $+\mathrm{V} * r]{ }^{22}$ While this part of the negator is compulsory in most languages with the exception of some cases where only the postverbal element is used, like in western Tarifit (Lafkioui 2007: 234-236) ${ }^{23}$-, the second part that usually follows the syntactic head may be optional - as an intensifier or required, depending on the negation context. The discontinuous marker is also employed in non-verbal predication, even in a more extended way than in North African Arabic, usually in contexts indexing existential values. However, the Berber languages make use of continuous markers too, which are based on Berber elements as well as on Arabic elements. ${ }^{24}$

\subsection{A new discontinuous negator}

The Moroccan Arabic variety of Oujda (MAO) provides abundant evidence of the existence of a new discontinuous negation marker which was created under contact influence from Berber, i.e. the hybrid morpheme $m a \_b u$. Its second constituent $b u$ is borrowed from Tarifit (Rif Berber, North Morocco; see Figure 1 in Section 1), which is the only Berber language in which this morpheme occurs (Lafkioui 1996, 1999: II/Chapter 2, 2007: 234-236, 2011a: 62-69). ${ }^{25}$

22. Different hypotheses have been proposed regarding the etymological origin of the two components of the negation operator in Berber, for example Galand (1995), Chaker (1996) and Brugnatelli (2011).

23. It is, however, in free variation with preverbal negation. For other cases with enclitic negation, see Brugnatelli (1987).

24. Grammaticalized amalgams are frequent in Berber.

25. Concerning the origin of this marker, no conclusive explanation is available. However, two options may be envisaged: the first one relates to the Tuareg Berber verb iba (and variants) signifying meanings such as 'there is no', 'cessation of' and 'lack of', of which the derived form ăba is used in optative constructions (Prasse et al. 2003: 2). Texts from the Ayer region (Niger) prove the existence of this verb as a negation adverb, i.e. ebaw 'no, really!' (Petites sœurs de Jésus 1974: 65). The second option has to do with the Arabic nomi- 
Indeed, this element (or its spirantized variant $\underline{b} u$ ) is part of all sorts of frequently used negators in Tarifit, such as $u$ bu, ur $b u, w a$ bu and war $\quad b u$, which perfectly correspond to the innovated hybrid morpheme of MAO on a structural as well as a functional level.

Examples:

$$
\begin{array}{lllll}
u & n n a-n & \underline{b} u & \text { awar } & h \text {-as. } \\
\text { NEG } & \text { PERF-3MPL } & \text { NEG } & \text { word } & \text { on }+3 \text { SG }
\end{array}
$$

'They did not say a word about him/her.'

$$
\begin{array}{llll}
u \quad & \dot{g} \bar{a}-s & \underline{b} u & \underline{t a m t t u t} . \\
\text { NEG } & \text { at+3SG } & \text { NEG } & \text { women } \\
\text { 'He has not got a wife.' } &
\end{array}
$$

These Berber utterances demonstrate verbal predication (example 76) and non-verbal predication (example 77), both negated by means of the morpheme $u \_b u$. The second element is compulsory and is necessarily followed by a noun (in its free state) functioning as an object complement.

Data from MAO do not only reveal the presence of the innovated morpheme containing exactly the same element $b u$, but also prove that it shares even the structural and functional features with Tarifit (see also Section 4.2.).

Examples:

$$
\begin{array}{llllll}
m a & \check{s} r a-w & b u & l-h a w l i & \text { had } & l-\varepsilon a \bar{m} m . \\
\text { NEG } & \text { PERF-3PL } & \text { NEG } & \text { DEF-sheep } & \text { PROX } & \text { DEF-year }
\end{array}
$$

'They did not buy a sheep this year.'
(79) ma eand-na bu d-ḑw $\quad f$ d-dār l-qdima. NEG at+1PL NEG DEF-electricity in DEF-house DEF-old 'We do not have electricity at the old house.'

As in Tarifit, the post-head element $b u$ is associated with a determined subsequent object, regularly marked by the definite article in MAO. The nega-

nal modifier and determinant $b u$ (e.g. $b u$ rās 'him with the head' > 'big headed one') that occurs in both Arabic and Berber data. 
tor $m a \_b u$ is used for basic negation in descriptive contexts. Compared to its major functional contender $m a$ $\check{s}$, this marker is much more restricted when it comes to its combinatorial options, its syntagmatic distribution and its functional roles. Since it needs to be combined with a determined object, its structural potential is limited to certain verbal configurations and to prepositional predicative configurations or some other quasi-verbal structures. These limitations are reflected in the distributional order, as the discontinuous marker is required to surround the verbal or non-verbal predicative head. Therefore, its second element does not function as a tool that demarcates the negation scope and may occupy different positions in the syntagm. These structural restrictions are related to functional roles that are of a descriptive nature, supported by highly referentialized notions conveying existential values. Expressive negation with $m a \_b u$ only occurs when an appropriate intonation backs up the whole structure.

Other examples confirming the structural and functional correspondence between the negation system of MAO and of Tarifit with respect to this contact-induced phenomenon are these Berber equivalents of example (78) and $(79):^{26}$

(80) $u \quad$ ss $\dot{g} i-n \quad \underline{b} u \quad$ izmar $\operatorname{asagg}^{w} a s-a$.

NEG PERF-3MPL NEG sheep year+PROX

'They did not buy a sheep this year.'

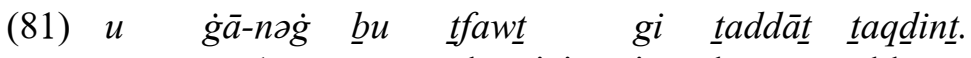

NEG at+1PL NEG electricity in house old

'We do not have electricity at the old house.'

\subsection{Innovated negation patterns}

The adoption of the new negation marker $m a$ $b u$ in MAO had some interesting implications on its negation system. It triggered a restructuring of its existing morphosyntactic patterns by introducing a new general pattern:

26. Besides examples (76) and (77) and numerous records from Lafkioui (1996, 1999: II/Chapter 2, 2007: 234-236, 2011a: 62-69). 


\section{New general negation pattern:}

$m a+\mathrm{PS}+b u+\mathrm{O}(\mathrm{DET})$

This innovated pattern is characterized by its fixed morphosyntactic order in which the determined post-head noun as an object complement is a prerequisite. It enfolds two sub-patterns, one applying to verbal predication (examples 78, 82, and 83) and another one related to non-verbal predication (examples 79, 84, and 85):

\section{New verbal negation pattern: \\ $m a+\mathrm{VPS}+b u+\mathrm{O}(\mathrm{DET})$}

(82)

ma lqā-t bu l-hall li-ha.

NEG PERF-3FSG NEG DEF-solution for+3FSG

'She did not find the solution for her (problem).'

$=$ 'She did not find a way to deal with her.'

ma ġadi i-ržac bu l-flūs $l$ mulā-h.

NEG AUX IMPERF-3MSG-return NEG DEF-money to owner+3MSG

'He won't give back the money to its owner.'

New non-verbal negation pattern:

$m a+\mathrm{NVPS}+b u+\mathrm{O}(\mathrm{DET})$

(84)

$\begin{array}{lllll}m a \quad f i-y a & b u & \check{z} \text {-žəhd } & b a s ̌ & n-n \bar{u} d . \\ \text { NEG in+1SG NEG } & \text { DEF-strenght } & \text { to } & \text { IMPERF-1SG-stand up } \\ \text { 'I do not have the energy to stand up.' }\end{array}$

(85)

$\begin{array}{lllll}m a \quad \text { cand-ək } & \text { bu lakart } & \text { kima } & \text { had-i? } \\ \text { NEG at+2SG NEG (DEF-)carte } & \text { like } & \text { PROX+FSG } \\ \text { 'Don't you have a card like this one?' } & \end{array}$

In both predication types, this new negator can be substituted by the discontinuous marker $m a$ $\check{s}$ without altering their distributional properties. Even on the semantic level, no distinctive values are observed if no prosodic markers are involved. However, as a basic negator, $m a$ $b u$ is in complementary distribution with $m a$ $\check{s}$ (and variants) in all contexts where the latter is incompatible with directly ensuing objects. Functionally speaking, this means that, compared to the centring latitude of the discon- 
tinuous marker $m a$

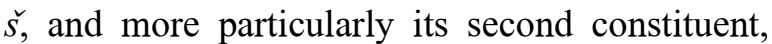
ma $b u$ is restrained to descriptive negation in which a precise referential object is asserted to be nonexistent. Moreover, since the new negator is strictly reserved for configurations with a determined (mostly definite) object, it has a particular paired but opposite relationship with $m a$ $\emptyset$ that is used in configurations with an undetermined object. On a functional level, this implies that $m a$ $b u$ is specialized in highly referential negation, in contrast with $[m a+\mathrm{HEAD}+\emptyset+\mathrm{O}$ (UNDET)], which is dedicated to the negation of dereferentialized notions.

Consequently, the generalized adoption of this new marker has caused a restructuring of the negation system of MAO: it introduced a specialized negation domain characterized by its high referentiality, which is morphosyntactically represented by structures containing determined objects. To a certain extent, this incorporation took away some of the functional domains of those discontinuous markers that are associated with variable referentiality degrees of the actualized or projected process or state. In other words, certain domains of the original system are reanalyzed as preferential for basic negation by means of the new operator; the same domains are reanalyzed as optional but not preferential with respect to the other discontinuous operators.

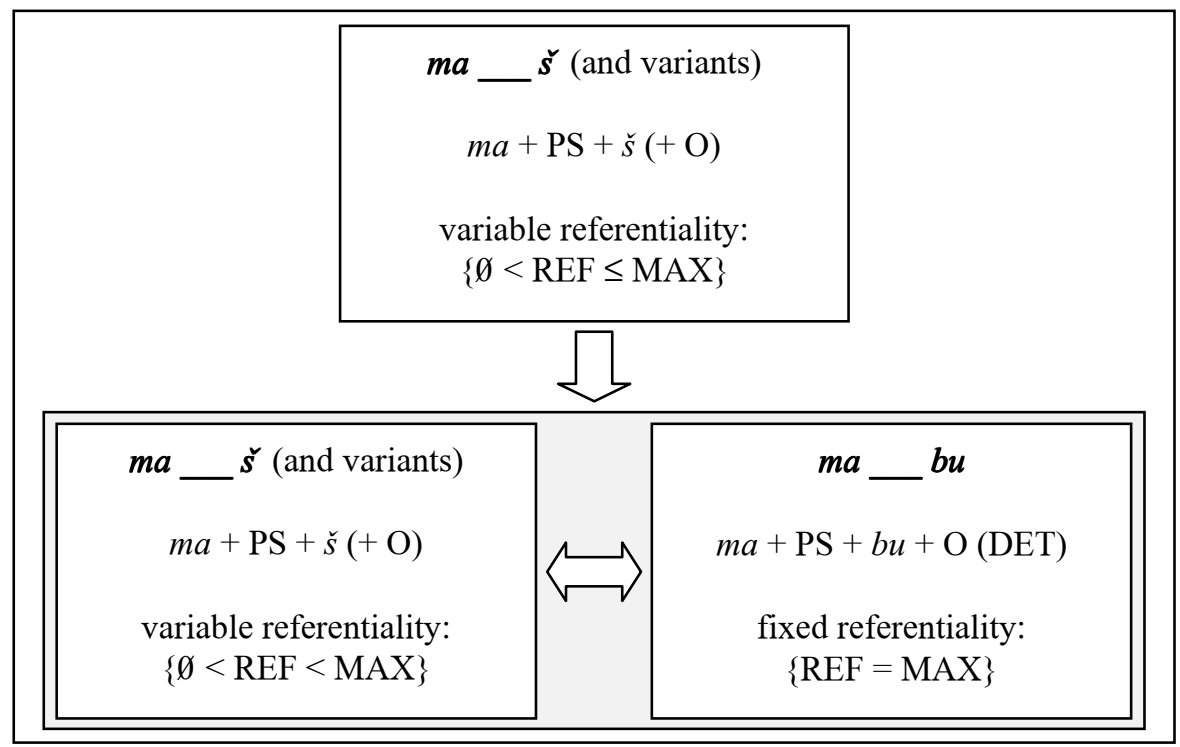

Figure 2. Reinvented negation system of MAO 


\subsection{Who borrowed from whom?}

The city of Oujda and its surroundings, originally Berber speaking (mainly Zenati language group), is of economic and political importance because of its strategic location on the border between East Morocco and West Algeria (see Figure 1, Section 1). Its role as an ancient and intensely active trading passage towards all directions is mostly responsible for its linguistic and cultural diversity. Yet, this diversity is still characterized by a considerable presence of Berber speaking people. In the last three decades, they have become even more prevalent due to, inter alia, students coming from Berber speaking areas outside Oujda (e.g. Berkane, Nador, Alhoceima, Figuig) who want to study at the relatively new University and often even settle there afterwards.

Until now, the negation with $m a$ $b u$ has only been attested, at least in a systematic way, in the region of Oujda (particularly in the city). At the same time, the diverse corresponding Berber variants are displayed in most of the regions of the large Rif area. Therefore, it is most likely that the borrowing direction occurred from Berber into Arabic (see Figure 1: dark grey zone). Especially since the users of this new negator also, and even mostly, speak Arabic and have no command of any Berber language. Furthermore, Tarifit has provided regular diachronic accounts of this phenomenon for at least a century, whereas for MAO, the informants have not always been able to confirm its existence prior to their own language practices (e.g. that of their parents and grandparents), which are mainly limited to the first and second generation. Even though no studies have reported on this phenomenon for other parts of North Africa (not even for Algeria), it would be of great interest to extend the fieldwork area across the Moroccan-Algerian border in order to verify whether it exists there too. If it does occur in the Arabic speaking parts on a considerable scale and in a regular way, the borrowing direction could be from Arabic into Berber. A valid explanation could be, for instance, that $m a$ $b u$ was adopted and then reanalyzed into Berber by Tarifit speaking people who immigrated to this region during the colonial period for economic reasons and who came back after the independence. ${ }^{27}$ Then again, Berber locutors could also have introduced this variant in the area through migration. Still, this is not supported by the actual data, which point to Berber as the borrowing source of the negation phenomenon at hand. These data also suggest that its adoption, acquisition

27. I have numerous oral narrative testimonies of this economic migration. 
and diffusion are chiefly motivated by system-internal properties (see Section 4.1. and 4.2.), since social factors such as prestige or community solidarity nearly do not apply to this case.

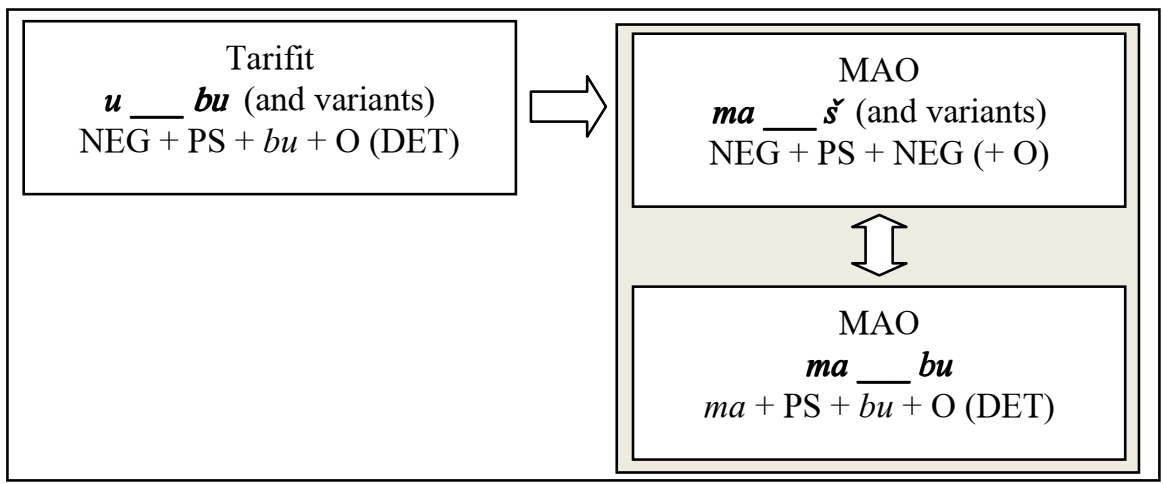

Figure 3. Contact-induced negation patterns in MAO

\section{Conclusion}

The addressed negation phenomena engendered by contact between Moroccan Arabic (MAO) and Berber (Tarifit) are examples of how language is constantly modulated in the form of innovations that may emerge in structurally layered and causal formations dictated by system-based properties. The several cases examined in this chapter show that even though innovations are induced by contact (i.e. extra-linguistic parameters), their diffusion and development can also be linguistically motivated (i.e. formal and functional parameters). Whether or not the new negation variants (form and structure) are widely distributed across the Moroccan Arabic varieties of the studied area is largely determined by system-internal factors such as structure adequacy and systematization of specific complementary combinatorial and distributional patterns connected with defined enunciative functions. Therefore, it is important to consider language change and diffusion not solely from a social perspective ("propagation" as in Croft 2000: 38, 178), but also in terms of how the variants are formally and functionally integrated into ever-changing linguistic structures (Lafkioui 2009, 2011b). 
Another interesting finding is that Moroccan Arabic - and even North African Arabic in genera ${ }^{28}$ - proves that there is a significant relationship between negation, modality and expressiveness, which I would explain as follows: the full occurrence of the discontinuous negation marker in verbal configurations mainly relates to descriptive predication with a variable negation scope. This variability depends on the position of the postverbal negator, which at the same time adds a certain degree of referentiality $(\{\mathrm{MIN}<\mathrm{REF}<\mathrm{MAX}\})$ to the selected discursive object. This is what I label as basic negation, unless expressive cognates of the postverbal intensifier $\check{s}$ (or variants) are employed (e.g. $\check{s} i, \check{s} a y$ ) for emphatic purposes. Conversely, marked negation chiefly engages the absence of the postverbal element (NEG $\emptyset)$, a procedure through which all kinds of modal and expressive values, in addition to existential ones, are asserted. However, referentiality is reduced here, even to $\emptyset$ in some cases (e.g. $[\mathrm{V}+\mathrm{S}+\mathrm{O}$ $(=\mathrm{UNDET})]):\{\varnothing \leq \mathrm{REF}<\mathrm{MAX}\}$. Pragmatically speaking, this implies that the absence of the postverbal negator allows for the fine-tuning of the discursive investment of the enunciators. A distinction between basic versus marked is also displayed with respect to the nature of the preverbal negator: while the item $m a$ is generally related to descriptive and hence basic negation - especially when combined with the postverbal $\check{s}-$ the item $l a$ is usually restricted to modal and expressive use (i.e. marked negation).

Compared to verbal negation, the inverse of the opposition [basic negation versus marked negation] is observed in non-verbal configurations. In other words, discontinuous negation marking stands for modality and expressiveness, while continuous negation marking signifies descriptive meanings that are connected with semantic values indicating an identification of the referential object, its localization or its attribution to a defined semantic category. The only exception is that of quasi-verbal constructions in which the nominal head tends to behave like a verbal predicate and hence makes use of the discontinuous negator for basic negation.

Cases such as the hybrid negator $m a-b u$ in MAO, occurring in specific complementary morphosyntactic configurations referring to assertoric values, suggest that it is basic negation that is predominantly subject to change in the asymmetrical negation system of North African Arabic. Accordingly, as far as the linguistic level is concerned, the evolution dynamics of negation in this area are significantly motivated by functional needs regarding descriptiveness and referentiality.

28. Except Bedouin varieties such as Hassaniyya. 
In contrast with the negation system of Classical Arabic, North African Arabic has probably undergone the following transformation stages with respect to basic verbal negation:

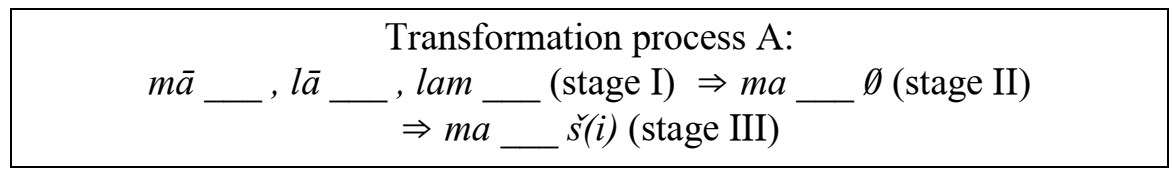

Stage II is merely attested in some southern varieties such as Hassiniyya and Skura in Morocco. It is common, though, in the Arabic varieties spoken in sub-Saharan Africa (e.g. Sudan and Chad) and in the Middle-East. From this stage, a discontinuous marker was created (stage III), which currently functions as the principal negator in North Africa. It is beyond the scope of this chapter to explain the motivation behind these diachronic changes, in particular the progression from stage II to stage III. Nevertheless, it should be mentioned that Brugnatelli's $(1987,2002,2005)$ hypothesis about the Berber origin of this latter innovation in Arabic is appealing as a basis for further investigation, especially when it comes to the Arabic part. He draws on a compelling parallel between the comparative Berber data and the Arabic case of the Dakhla-Oasis (Woidich 1995-97). Basically, he suggests that Berber had a postverbal negator at a proto-Berber level, which provoked the emergence of negative aspectual forms (at practically a panBerber level) due to accent dislocation and vowel reduction. For reasons of redundancy, some of the Berber languages have lost this postverbal item. Those which conserved it, reanalyzed it as a negation marker similar to stage III in Arabic. They did so at a later time through contact with those Arabic varieties that had already undergone this transformation at the time in question. Given that Berber already had a discontinuous marker before its postverbal development, i.e. preverbal negator + negative aspectual marker, it is problematic to assume a borrowing from Arabic while ignoring this important fact (Lucas 2007). As a matter of fact, many Berber languages are characterized by a triple negation marking: preverbal negator (particle) + mesoverbal negator (apophonic aspectual form) + postverbal negator (particle). Consequently, it is reasonable to assume that Berber was a borrowing source for stage III in North African Arabic - even when this theory is based on a case of double negation marking in Berber (SchmittBrandt 1979) - or that both Berber and Arabic have been the subject of an independent evolution. 
Additionally, the Arabic variety investigated in this study has developed a new negator that is in complementary distribution with the primary negator $m a \_r$, as described in the following diagram:

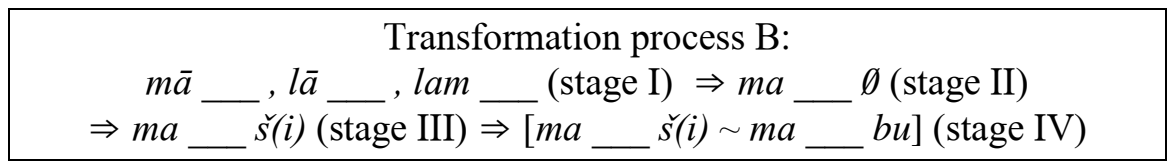

The diachronic change in MAO from stage III to stage IV was triggered by a borrowing process from Berber, in which not only a formal property was (partially) borrowed but also its corresponding constructions ("replica grammaticalization"; Heine \& Kuteva 2003: 539; see Section 4). At the basis of the diffusion of this phenomenon are system-based factors such as structural adequacy and generalization.

An interesting point that should also be noted in this conclusion, but definitely calls for additional research, even on a general comparative and typological level, is the existence of negative structures with none of the usual negation markers (i.e. apparent zero negation marking). These structures comprise nominals in topical position in the phase of grammaticalization (by means of adverbialization) towards new pre-head negation markers (Section 3.1.2., example 40). Furthermore, this remarkable development also accounts for the bipartite basic structure of verbal negation in Arabic, which is constantly adjusted to both linguistic and extra-linguistic needs.

As regards marked negation (see diagram below), again stage II is only observed in a limited number of Bedouin varieties, whereas stage III is quite widespread in North Africa. On the other hand, stage I as well as stage II is frequently employed elsewhere in the Arabic speaking areas.

\begin{aligned} & Transformation process A: \\ &$l a \_ \emptyset($ stage I $) \Rightarrow m a \_ \\ &$\hline\end{aligned}

Moreover, the most western parts of North Africa (especially Morocco) give evidence of a discontinuous marker directly derived from the first stage, as is shown in the next diagram:

$$
\begin{aligned}
& \text { Transformation process B: } \\
& \text { la__ } \emptyset(\text { stage I }) \Rightarrow l a \_s(i) \text { (stage II) }
\end{aligned}
$$


As this evolution process is simultaneously attested with the process exposed in A, the negator $m a \_s(i)$ may also have been created by means of the following course of action:

Transformation process $\mathrm{C}$ :

$l a \_\varnothing($ stage I $) \Rightarrow l a \_\check{s}(i) \quad($ stage II $) \Rightarrow m a \_s(i)$ (stage III)

Why and when all these transformations occurred in Arabic and how they challenge Jespersens' Cycle model (Jespersen 1917: 4) is definitely outside the realm of this mainly dialectological contribution. Yet, it is a topic that is certainly in need of further investigation, not only from a historical (AfroAsiatic) and typological viewpoint but also from an areal perspective that takes into account the contact situations and phenomena that led to the language change and diffusion. 


\section{References}

Adila, Aziz

1996 La négation en arabe marocain. In La négation en berbère et en arabe maghrébin, Salem Chaker, and Dominique Caubet (eds.), 99116. Paris: L'Harmattan.

Aguadé, Jordi, and Mohammad Elyaacoubi

1995 El dialecto arabe de Skūra (Marruecos). Madrid: Consejo Superior de Investigaciones Cientificas.

Boucherit, Aziza

2002 L'arabe parlé à Alger. Aspects sociolinguistiques et énonciatifs. Paris/Louvain: Peeters.

Brugnatelli, Vermondo

1987 La negazione discontinua in berbero e in arabo magrebino. In Atti della 4 a Giornata di studi camito-semitici ed indoeuropei, Giuliano Bernini, and Vermondo Brugnatelli (eds.), 53-62. Milan: Unicopli.

2002 Les thèmes verbaux négatifs du berbère: quelques réflexions. In Articles de linguistique berbère. Mémorial Werner Vycichl, K. NaïtZerrad (ed.), 165-180. Paris: L'Harmattan.

2005 Voyelles et accents dans l'histoire du berbère. In Proceedings of the $10^{\text {th }}$ Meeting of Hamito-Semitic (Afroasiatic) Linguistics, Pelio Fronzaroli, and Paolo Marrassini (eds.), 371-380. Firenze: Università di Firenze.

2011 Négations, participes et figement en berbère: nouvelles hypothèses. In "Parcours berbères". Mélanges offerts à Paulette Galand-Pernet et Lionel Galand pour leur 90e anniversaire, Amina Mettouchi (ed.), 521-532. Köln: Köppe.

Caubet, Dominique

1992 Deixis, aspect et modalité, les particules $h \bar{a}$ - et $r \bar{a}$ - en arabe marocain. In La deixis, Marie-Annick Morel, and Laurent Danon-Boileau (eds.), 139-49. Paris: P.U.F.

1996 La négation en arabe maghrébin. In La négation en berbère et en arabe maghrébin, Salem Chaker, and Dominique Caubet (eds.), 7997. Paris: L'Harmattan.

Chaâbane, Nadia

1996 La négation en arabe tunisien. In La négation en berbère et en arabe maghrébin, Salem Chaker, and Dominique Caubet (eds.), 117-134. Paris: L'Harmattan.

Chaker, Salem

1996 Quelques remarques préliminaires sur la négation en berbère. In $L a$ négation en berbère et en arabe maghrébin, Salem Chaker, and Dominique Caubet (eds.), 9-22. Paris: L'Harmattan. 
Cohen, David

1984 La phrase nominale et l'évolution du système verbal en sémitique. Etude de syntaxe historique. Paris: Société de Linguistique de Paris.

Croft, William

2000 Explaining Language Change: An Evolutionary Approach. Harlow: Longman.

Elhalimi, Brahim

1996 La négation dans le parler arabe de Mazouna (Algérie). In La négation en berbère et en arabe maghrébin, Salem Chaker, and Dominique Caubet (eds.), 135-162. Paris: L'Harmattan.

Galand, Lionel

1995 La negation en berbère. Matériaux arabes et sudarabiques (GEL$L A S$, nouvelle série) 8: 169-181.

Harrell, Richard S.

1962 A Short Reference Grammar of Moroccan Arabic. Washington D.C.: Georgetown University Press.

Heine, Bernd, and Tania Kuteva

2003 On contact-induced grammaticalization. Studies in Language 27: 529-572.

Iaaich, Jamal

1996 La négation en hassaniyya de Tan-Tan (Maroc). In La négation en berbère et en arabe maghrébin, Salem Chaker, and Dominique Caubet (eds.), 135-162. Paris: L'Harmattan.

Jespersen, Otto

1917 Negation in English and Other languages. Copenhagen: Host \& Son. Lafkioui, Mena

1996 La négation en tarifit. In La négation en berbère et en arabe maghrébin, Salem Chaker, and Dominique Caubet (eds.), 49-77. Paris: L'Harmattan.

1999 Syntaxe intégrée de l'énoncé non-verbal berbère. $\mathrm{PhD}$, INALCO (Paris).

2002 L'intonation et ses fonctions syntaxiques en rifain. In Articles de linguistique berbère. Mémorial Werner Vycichl, Kamal Naït-Zerrad (ed.), 253-281. Paris: L'Harmattan.

2007 Atlas linguistique des variétés berbères du Rif. Köln: Köppe.

2009 Synchronic and diachronic linguistic variation as an indicator of language change and diffusion in Tarifit. Studi Magrebini (Nuova Serie) 6: 65-84.

2010 La topicalisation en berbère: formes et structures. In Études berbères $V$ - Essais sur des variations dialectales et autres articles, Dymitr Ibriszimow, Rainer Vossen, Harry Stroomer, and Maarten Kossmann (eds.), 121-132. Köln: Köppe. 
2011a Etudes de la variation et de la structuration linguistiques et sociolinguistiques en berbère. Köln: Köppe.

$2011 \mathrm{~b}$ How system-internal linguistic factors indicate language change and diffusion. A geolinguistic analysis of Berber data. Dialectologia et Geolinguistica 19: 62-80.

2011c Intonation et topicalisation en berbère. In Mélanges offerts à Paulette Galand-Pernet \& Lionel Galand pour leur 90ème anniversaire, Amina Mettouchi (ed.), 387-397. Köln: Köppe.

Lucas, Christopher

2007 Jespersen's Cycle in Arabic and Berber. Transactions of the Philological Society 105(3): 398-431.

Marçais, Philippe

1977 Esquisse grammaticale de l'arabe maghrébin. Paris: Maisonneuve.

Owens, Jonathan

1984 A Short Reference Grammar of Eastern Libyan Arabic. Wiesbaden: Harrassowitz.

Pennacchietti, Fabrizio

1967 Sull'origine della particella negativa araba $m \bar{a}$. Annali dell'Istituto Orientale di Napoli 18: 15-23.

Petites soeurs de Jésus

1974 Contes touaregs de l'Aïr. Paris: SELAF.

Prasse, Karl-G, Ghoubeïd Alojaly, and Mohamed Ghabdouane

2003 Dictionnaire touareg-français $(A-L)$. Copenhagen: Museum Tusculanum Press.

Schmitt-Brandt, Robert

1978 Berberische Adstrateinflüsse im maghrebinischen Arabisch. Folia Linguistica 13: 229-235.

Taine-Cheikh, Catherine

1995-96 Trois points de vue sur la negation $m \bar{a}$ dans le dialecte arabe de Mauritanie. Matériaux arabes et sudarabiques (GELLAS, Nouvelle Série) 7: 11-61.

2000 Les emplois modaux de la negation $l \bar{a}$ dans quelques dialects arabes. Comptes rendus du GLECS 33: 39-86.

Tesnières, Louis

1959 Eléments de syntaxe structurale. Paris: Klincksieck.

Vanhove, Martine

1994 Sur le fonctionnement de la négation en maltais. Matériaux arabes et sudarabiques (GELLAS, Nouvelle Série) 6: 141-167.

Wehr, Hans

1953 Zur Funktion arabischer Negationen. ZDMG 103: 27-39. 
Woidich, Manfred

1995-97 Negation in the Egyptian Arabic dialect of the Dakhla-Oasis: a case of rule morphologization. Mediterranean Language Review 9: $13-28$.

Youssi, Abderrahim

1992 Grammaire et lexique de l'arabe marocain moderne. Casablanca: Wallada. 
